\title{
Effects of Glycerol on the Metabolism of Broilers FED Increasing Glycerine Levels
}

\section{-Author(s)}

Romano GG

Menten JFM'

Freitas LW'

Lima MB'

Pereira R

Zavarize $\mathrm{KC}$

Dias CTS"

Department of Animal Science, Escola Superior de Agricultura "Luiz de Queiroz", Universidade de São Paulo, Piracicaba, Brazil.

" Department of Statistics and Agricultural Experimentation, Escola Superior de Agricultura "Luiz de Queiroz", Universidade de São Paulo, Piracicaba, Brazil.

\section{Mail Adress}

Corresponding author e-mail address Gislaine Goretti Romano

Avenida Pádua Dias, 11 - Cep: 13418-900 Piracicaba - São Paulo

E-mail address: gislaine.romano@gmail.com

\section{nKeywords}

Alternative feedstuffs, energy source, nutrition, feed.

\section{ABSTRACT}

This study evaluated the metabolic response of broilers fed diets containing increasing crude glycerine levels in two bioassays. Birds were house in metabolic cages, and were distributed according to a completely randomized experimental design with five treatments of 4 replicates each ( $1^{\text {st }}$ assay: 5 birds/ cage; $2^{\text {nd }}$ assay: $1-20$ days $=8$ birds/ cage, and 21-42 days $=4$ birds/cage). Treatments consisted of a control diet based on corn and soybean meal, and four other diets containing $2.5 \%, 5.0 \%, 7.5 \%$ and $10.0 \%$ glycerine derived from biodiesel. In experiment I, there was no effect $(p>0.05)$ of glycerol level on liver weight or blood parameters. Serum blood glycerol levels of the birds fed $10 \%$ crude glycerine increased during the first nine days of diet intake $(p<0.05)$. In experiment II, water intake increased $(p<0.05)$ in the birds fed 7.5 and $10.0 \%$ crude glycerine at 4 and 8 days of age. Feed intake increased $(p<0.05)$ on days 8 and 12 in birds fed 2.5 and $7.5 \%$ glycerine. Fecal moisture increased $(p<0.05)$ in birds fed diets with $5.0,7.5$, and $10.0 \%$ crude glycerine on days 16 and 20 . Ileal content moisture was not different ( $p>0.05)$ among treatments when birds were 42 days old. High dietary glycerine levels may induce metabolic change in broilers, such as increased blood glycerol level, water intake and fecal moisture.

\section{INTRODUCTION}

Poultry production is the animal industry segment that most developed in the last few decades, particularly because it is very competitive relative to the other industries (Belusso \& Hespanhol, 2010).

Poultry nutrition researchers have looked for alternatives to formulate increasingly efficient and economical diets, as feed cost accounts for approximately $70 \%$ of total production costs.

In addition to agricultural research, several studies have been carried out on the use of renewable energy sources, particularly biodiesel. With the increasing production of biodiesel, a potential new energy feedstuff is available: crude glycerine, a byproduct of biodiesel production (Peres et al., 2005).

The use of byproducts in livestock feeds may reduce production costs and consequently increase profitability. Depending on its price, glycerine can partially replace corn in animal feeds (Cerrate et al., 2006) as it is energy-rich (4.320 kcal gross energy per $\mathrm{kg}$ for pure glycerol) and efficiently metabolized by animals.

Glycerine is the commercial name of glycerol, an alcohol that is part of all triglyceride molecules found in animal and plant tissues (Pond et al., 2005). After absorption, glycerol can be converted in glucose (Emmanuel et al., 1983) via gluconeogenesis or oxidized for 
the production of energy via glycolysis and citric acid cycle (Rosebrough et al., 1980), which is the metabolic destination of $60 \%$ of glycerol under basal conditions (Robergs \& Griffin, 1998).

Therefore, the objective of this study was to identify the metabolic response of broilers fed diets containing crude glycerine and the effects of this feedstuff on some blood parameters.

\section{MATERIALS AND METHODS}

Two bioassays were carried out at the experimental poultry house of the Department of Animal Science Non-Ruminant Sector of Escola Superior de Agricultura "Luiz de Queiroz", located in Piracicaba, SP, Brazil. In both experiments, increasing levels of crude glycerine $(0,2.5 \%, 5.0 \%, 7.5 \%$, or $10.0 \%)$ were added to broiler diets. Crude glycerine was purchased from the company Caramuru Alimentos Ltda and its composition was analyzed in a commercial laboratory (Table 1). The ingredients and calculated nutritional composition of the experimental diets are presented in Tables 2, 3, 4, and 5. The gross energy value of 3,620 $\mathrm{kcal} / \mathrm{kg}$ was obtained in a calorimetric bomb and for diet formulation, the metabolizable energy value was considered as $90 \%$ of the gross energy value $(3,258$ $\mathrm{kcal}$ AMEn/kg). Glycerol, total chloride, and sodium contents of the glycerine were measured to correct diet formulation.

Table 1 - Composition of the crude glycerine included in the diets

\begin{tabular}{lcc}
\hline Analyses & Unit & Result \\
Glycerol & $\%$ & 83.63 \\
Humidity (Karl Fischer) & $\%$ & 11.18 \\
Ether extract & $\%$ & 0.09 \\
Ashes & $\%$ & 6.97 \\
Total chloride & $\%$ & 4.91 \\
Sodium & $\%$ & 1.83 \\
ph in water solution & - & 6.16 \\
Methanol & $\mathrm{mg} / \mathrm{kg}$ & 397 \\
\hline
\end{tabular}

In the experiment I, 100 20-d-old male Cobb-500 ${ }^{\circledR}$ broilers were used. Birds were housed in a metabolism room containing two batteries of 12 metal cages each for growing broilers. Cages were $0.70 \mathrm{~m}$ long, $0.66 \mathrm{~m}$ wide, and $0.34 \mathrm{~m}$ high, with wire mesh floor, and equipped with stainless steel trough feeder and drinker and a removable tray under the cage.

Before the experiment started, birds were submitted to period of adaptation to the cages and diets for three days. Environmental temperature was daily recorded, and birds were maintained under thermoneutral conditions according to age with the aid of fans and foggers. The nutritional requirements treatments consisted of five increasing levels of crude glycerine inclusion $(0,2.5 \%, 5.0 \%, 7.5 \%$, or $10.0 \%$; Table 4) in diets based on corn and soybean meal formulated according to the feedstuff chemical composition and nutritional requirements proposed by Rostagno et al. (2011). Birds were distributed according to a completely randomized experimental design consisting of five treatments with four replicates of five birds each, totaling 20 experimental units. Water and feed were offered ad libitum. Crude glycerine was included in the nutritional matrix using the value of 3,258 kcal AMEn/kg and the sodium and chlorine values were adjusted according to the composition of glycerine.

Blood samples were collected when birds were 23, $26,29,32$, and 53 days old to quantify glycerol serum level. Approximately $5 \mathrm{~mL}$ of blood were collected from four birds per treatment by brachial vein puncture. The blood was then centrifuged at 3,000 rpm for $5 \mathrm{~min}$ at $4^{\circ} \mathrm{C}$ to obtain the serum, which was stored in a freezer $\left(-18^{\circ} \mathrm{C}\right)$ until biochemical analysis.

Four birds per treatment were sacrificed at 35 days of age by neck dislocation to collect the liver, which was immediately frozen at $-18^{\circ} \mathrm{C}$.

Liver and serum glycerol levels were quantified by ultra-performance liquid chromatography (UPLC; Acquity ${ }^{\top M}$, Waters). The main advantage of this method is its excellent efficiency in separating analytes, even with high flow rates during the mobile phase. As a result, the resolution is better, analysis time is reduced, and detectability is improved (Swartz, 2005).

Before blood collection for the determination of cholesterol and triacylglycerol levels, birds were feedfasted for 12 hours. On the following day, blood was collected by brachial vein puncture of four birds per treatment at 36 days of age. Blood was collected in vacutainer ${ }^{\circledR}$ tubes with anticoagulant to allow plasma separation. Tubes were centrifuged at 3,000 rpm for 5 min at $4^{\circ} \mathrm{C}$, and the plasma was removed using a manual pipette and stored at $-18^{\circ} \mathrm{C}$. Cholesterol and triacylglycerol levels were determined by the colorimetric enzymatic method using commercial kits $\left(\right.$ Laborlab $^{\circledR}$ ) with reading at $505 \mathrm{~nm}$ in a spectrophotometer, according to the method of Lumeij (1997), and expressed in $\mathrm{mg} / \mathrm{dL}$.

In experiment II, 160 male Cobb-500 ${ }^{\circledR}$ broilers purchased from a commercial hatchery were used. In this experiment, water consumption, feed intake, and fecal and ileal content moisture were evaluated as a function of increasing dietary glycerine levels. Birds were distributed to the same treatments described in 
Experiment I, but the feeds were formulated according to rearing phase: pre-starter (1-7 days), starter (7-21 days), grower (21-35 days), and finisher (35-42 days), as shown in Tables 2, 3, 4, and 5 . The bioassay was carried out in two phases. In the first phase, groups of eight birds were reared in metabolic cages provided with heating. In the second phase, after 21 days of age, birds were transferred to other cages in order to have four birds per cage. Cages were equipped with a tray for excreta collection, and trough feeder and drinker. Environmental temperature was daily recorded, and birds were maintained under thermoneutral conditions according to age.

In both phases, birds were distributed according to a completely randomized experimental design consisting of five treatments with four replicates of five birds each, totaling 20 experimental units.
Water consumption and feed intake were recorded for 24h every four days (1-40 days of age). The excreta produced during a 3-h period were collected after day 16 because heating was previously used. Excreta were collected on the same days that feed intake and water consumption were recorded. The collected excreta were placed in duly identified aluminum recipients and frozen at $-18^{\circ} \mathrm{C}$ until the end of the collection period. Excreta were then thawed, homogenized, and a significant sample was removed and weight. Samples were pre-dried in a forced-ventilation oven at $55^{\circ} \mathrm{C}$ for 72 hours, weighed, ground in $1 \mathrm{~mm}$-mesh mill, and dried in the oven at $105^{\circ} \mathrm{C}$ for 24 hours to determine final dry matter content.

Four birds per treatment were sacrificed by neck dislocation for ileal digesta collection. The ileum was determined as the section between Meckel's

Table 2 - Ingredients and calculated nutritional composition of the pre-starter diets.

\begin{tabular}{|c|c|c|c|c|c|}
\hline \multirow[b]{2}{*}{ Ingredients } & \multicolumn{5}{|c|}{ Glycerine inclusion (\%) } \\
\hline & 0 & 2.5 & 5.0 & 7.5 & 10.0 \\
\hline Ground corn & 48.905 & 45.940 & 42.970 & 40.002 & 37.035 \\
\hline Soybean meal & 43.586 & 44.081 & 44.580 & 45.078 & 45.574 \\
\hline Soybean oil & 3.426 & 3.517 & 3.606 & 3.696 & 3.786 \\
\hline Glycerine & 0.000 & 2.500 & 5.000 & 7.500 & 10.000 \\
\hline Dicalcium phosphate & 1.863 & 1.867 & 1.871 & 1.875 & 1.878 \\
\hline Calcitic limestone & 0.913 & 0.909 & 0.906 & 0.903 & 0.900 \\
\hline Salt & 0.508 & 0.394 & 0.280 & 0.165 & 0.052 \\
\hline DL-methionine & 0.325 & 0.327 & 0.331 & 0.334 & 0.337 \\
\hline L-lysine $\mathrm{HCl}$ & 0.143 & 0.134 & 0.125 & 0.116 & 0.107 \\
\hline L-threonine & 0.046 & 0.046 & 0.046 & 0.046 & 0.046 \\
\hline Vitamin supplement ${ }^{1}$ & 0.100 & 0.100 & 0.100 & 0.100 & 0.100 \\
\hline Choline chloride $60 \%$ & 0.080 & 0.080 & 0.080 & 0.080 & 0.080 \\
\hline Anticoccidial agent ${ }^{2}$ & 0.050 & 0.050 & 0.050 & 0.050 & 0.050 \\
\hline Mineral supplement ${ }^{3}$ & 0.050 & 0.050 & 0.050 & 0.050 & 0.050 \\
\hline Growth promoter ${ }^{4}$ & 0.005 & 0.005 & 0.005 & 0.005 & 0.005 \\
\hline \multicolumn{6}{|l|}{ Calculated values } \\
\hline ME (kcal/kg) & 2.960 & 2.960 & 2.960 & 2.960 & 2.960 \\
\hline $\mathrm{CP}(\%)$ & 23.92 & 23.91 & 23.89 & 23.87 & 23.86 \\
\hline Dig. Met+cys (\%) & 0.953 & 0.953 & 0.953 & 0.953 & 0.953 \\
\hline Dig. methionine (\%) & 0.631 & 0.633 & 0.634 & 0.635 & 0.636 \\
\hline Dig. lysine (\%) & 1.324 & 1.324 & 1.324 & 1.324 & 1.324 \\
\hline Dig. threonine (\%) & 0.861 & 0.861 & 0.861 & 0.861 & 0.861 \\
\hline Calcium (\%) & 0.920 & 0.920 & 0.920 & 0.920 & 0.920 \\
\hline Avail. phosphorus (\%) & 0.470 & 0.470 & 0.470 & 0.470 & 0.470 \\
\hline Sodium (\%) & 0.220 & 0.220 & 0.220 & 0.220 & 0.220 \\
\hline Chlorine (\%) & 0.353 & 0.357 & 0.362 & 0.366 & 0.370 \\
\hline Potassium (\%) & 0.939 & 0.939 & 0.940 & 0.940 & 0.941 \\
\hline Number of Mongin $(\mathrm{mEq} / \mathrm{kg})$ & 236.19 & 235.11 & 234.03 & 232.95 & 231.87 \\
\hline
\end{tabular}

'Supplied per kg diet: Vitamin A, 9,000 IU; Vitamin D3, 2.500 IU; Vitamin E, 20 IU; Vitamin K3, 2.5 mg; Vitamin B1 (thiamin), 1.5 mg; Vitamin B2 (riboflavin), 6 mg; Vitamin B6 (pyridoxine), 3 mg; Vitamin B12 (cyanocobalamin), $12 \mu$; Pantothenic acid, 12 mg; Niacin, 25 mg; Folic acid, 0.8 mg; Biotin, 0.060 mg; Selenium, 0.25 mg. ${ }^{2}$ Coxistac - $12 \%$ salinomycin. ${ }^{3}$ Supplied per kg diet: Cu, 10 mg; Fe, 50 mg; Mn, 75 mg; Co, 1 mg; l, 1 mg; Zn, 50 mg. ${ }^{4}$ Halquinol BP 80: 60\% chlorohydroxyquinoline. 
Table 3 - Ingredients and calculated nutritional composition of the starter diets.

\begin{tabular}{|c|c|c|c|c|c|}
\hline \multirow[b]{2}{*}{ Ingredients } & \multicolumn{5}{|c|}{ Glycerine inclusion (\%) } \\
\hline & 0 & 2.5 & 5.0 & 7.5 & 10.0 \\
\hline Ground corn & 53.873 & 50.906 & 47.938 & 44.971 & 42.003 \\
\hline Soybean meal & 38.540 & 39.037 & 39.534 & 40.032 & 40.530 \\
\hline Soybean oil & 3.848 & 3.938 & 4.028 & 4.117 & 4.207 \\
\hline Glycerine & 0.000 & 2.500 & 5.000 & 7.500 & 10.000 \\
\hline Dicalcium phosphate & 1.534 & 1.538 & 1.542 & 1.545 & 1.549 \\
\hline Calcitic limestone & 0.945 & 0.942 & 0.939 & 0.936 & 0.932 \\
\hline Salt & 0.482 & 0.368 & 0.254 & 0.140 & 0.026 \\
\hline DL-methionine & 0.290 & 0.293 & 0.296 & 0.299 & 0.302 \\
\hline L-lysine $\mathrm{HCl}$ & 0.161 & 0.151 & 0.142 & 0.133 & 0.123 \\
\hline L-threonine & 0.042 & 0.042 & 0.042 & 0.042 & 0.043 \\
\hline Vitamin supplement $^{1}$ & 0.100 & 0.100 & 0.100 & 0.100 & 0.100 \\
\hline Choline chloride $60 \%$ & 0.080 & 0.080 & 0.080 & 0.080 & 0.080 \\
\hline Anticoccidial agent ${ }^{2}$ & 0.050 & 0.050 & 0.050 & 0.050 & 0.050 \\
\hline Mineral supplement ${ }^{3}$ & 0.050 & 0.050 & 0.050 & 0.050 & 0.050 \\
\hline Growth promoter ${ }^{4}$ & 0.005 & 0.005 & 0.005 & 0.005 & 0.005 \\
\hline \multicolumn{6}{|l|}{ Calculated values } \\
\hline ME (kcal/kg) & 3.050 & 3.050 & 3.050 & 3.050 & 3.050 \\
\hline $\mathrm{CP}(\%)$ & 22.02 & 22.01 & 22.00 & 21.98 & 21.96 \\
\hline Dig. met+cys (\%) & 0.876 & 0.876 & 0.876 & 0.876 & 0.876 \\
\hline Dig. methionine (\%) & 0.577 & 0.578 & 0.579 & 0.580 & 0.582 \\
\hline Dig. lysine (\%) & 1.217 & 1.217 & 1.217 & 1.217 & 1.217 \\
\hline Dig. threonine (\%) & 0.791 & 0.791 & 0.791 & 0.791 & 0.791 \\
\hline Calcium (\%) & 0.841 & 0.841 & 0.841 & 0.841 & 0.841 \\
\hline Avail. phosphorus (\%) & 0.401 & 0.401 & 0.401 & 0.401 & 0.401 \\
\hline Sodium (\%) & 0.210 & 0.210 & 0.210 & 0.210 & 0.210 \\
\hline Chlorine (\%) & 0.339 & 0.343 & 0.347 & 0.351 & 0.356 \\
\hline Potassium (\%) & 0.861 & 0.862 & 0.862 & 0.863 & 0.863 \\
\hline Number of Mongin $(\mathrm{mEq} / \mathrm{kg})$ & 216.01 & 214.93 & 213.85 & 212.77 & 211.69 \\
\hline
\end{tabular}

'Supplied per kg diet: Vitamin A, 9,000 IU; Vitamin D3, 2.500 IU; Vitamin E, 20 IU; Vitamin K3, 2.5 mg; Vitamin B1 (thiamin), 1.5 mg; Vitamin B2 (riboflavin), 6 mg; Vitamin B6 (pyridoxine), 3 mg; Vitamin B12 (cyanocobalamin), $12 \mu$; Pantothenic acid, 12 mg; Niacin, 25 mg; Folic acid, 0.8 mg; Biotin, 0.060 mg; Selenium, $0.25 \mathrm{mg} .{ }^{2}$ Coxistac $-12 \%$ salinomycin. ${ }^{3}$ Supplied per kg diet: Cu, 10 mg; Fe, 50 mg; Mn, 75 mg; Co, 1 mg; I, 1 mg; Zn, 50 mg. ${ }^{4}$ Halquinol BP 80: 60\% chlorohydroxyquinoline.

diverticulum and the ileocecocolic junction. Ileal content was collected, weighed, freeze-dried for 72 hours, and weighed again.

Blood parameters, liver weight, and liver glycerol level data were submitted to analysis of variance by the GLM PROC of SAS 9.2 statistical package. Means were compared by the test of Tukey at $5 \%$ probability level. Serum glycerol level, water consumption, feed intake, and excreta moisture data were submitted to analysis of variance considering the best covariance structure, as these were repeated measures in the flock, in order to evaluate the importance of the effects of treatment (diets), sampling times, and treatment vs. time interaction. If the effect of the diet or of the interaction was significant $(p<0.05)$, data were submitted to analysis of regression.

\section{RESULTS AND DISCUSSION}

The results of dietary crude glycerine inclusion vs. time of serum glycerol sampling are shown in Figure 1. There was an effect of the interaction $(p<0.05)$ between dietary glycerine levels and time of collection on serum glycerol levels, which increased on days 3, 6, and 9 in birds fed $10.0 \%$ glycerine and returned to the level of the controls after day 9.

In this study, birds fed up to $7.5 \%$ crude glycerine were capable of metabolizing glycerol easier than those fed $10 \%$, which is consistent with findings of Gianfelici (2009). According to Lin (1977), normal blood crude glycerine levels are $0.1 \mathrm{mM}$ in rats and 0.05-0.1 mM in humans. Simon et al. (1996) evaluated blood glycerol levels in broilers two hours after feeding and observed that those fed the control diet presented 
Table 4 - Ingredients and calculated nutritional composition of the grower diets.

\begin{tabular}{|c|c|c|c|c|c|}
\hline \multirow[b]{2}{*}{ Ingredients } & \multicolumn{5}{|c|}{ Glycerine inclusion (\%) } \\
\hline & 0 & 2.5 & 5.0 & 7.5 & 10.0 \\
\hline Ground corn & 56.531 & 53.564 & 50.596 & 47.629 & 44.661 \\
\hline Soybean meal & 35.302 & 35.799 & 36.295 & 36.792 & 37.291 \\
\hline Soybean oil & 4.817 & 4.906 & 4.997 & 5.086 & 5.176 \\
\hline Glycerine & 0.000 & 2.500 & 5.000 & 7.500 & 10.000 \\
\hline Dicalcium phosphate & 1.310 & 1.314 & 1.318 & 1.322 & 1.325 \\
\hline Calcitic limestone & 0.889 & 0.886 & 0.883 & 0.880 & 0.877 \\
\hline Salt & 0.458 & 0.344 & 0.230 & 0.115 & 0.002 \\
\hline DL-methionine & 0.269 & 0.272 & 0.275 & 0.278 & 0.281 \\
\hline L-lysine $\mathrm{HCl}$ & 0.150 & 0.141 & 0.132 & 0.123 & 0.113 \\
\hline L-threonine & 0.029 & 0.029 & 0.029 & 0.030 & 0.029 \\
\hline Vitamin supplement $^{1}$ & 0.080 & 0.080 & 0.080 & 0.080 & 0.080 \\
\hline Choline chloride $60 \%$ & 0.060 & 0.060 & 0.060 & 0.060 & 0.060 \\
\hline Anticoccidial agent ${ }^{2}$ & 0.050 & 0.050 & 0.050 & 0.050 & 0.050 \\
\hline Mineral supplement ${ }^{3}$ & 0.050 & 0.050 & 0.050 & 0.050 & 0.050 \\
\hline Growth promoter ${ }^{4}$ & 0.005 & 0.005 & 0.005 & 0.005 & 0.005 \\
\hline \multicolumn{6}{|l|}{ Calculated values } \\
\hline $\mathrm{ME}(\mathrm{kcal} / \mathrm{kg})$ & 3.150 & 3.150 & 3.150 & 3.150 & 3.150 \\
\hline $\mathrm{CP}(\%)$ & 20.74 & 20.72 & 20.71 & 20.70 & 20.68 \\
\hline Dig. met+cys (\%) & 0.826 & 0.826 & 0.826 & 0.826 & 0.826 \\
\hline Dig. methionine (\%) & 0.542 & 0.543 & 0.544 & 0.545 & 0.547 \\
\hline Dig. lysine (\%) & 1.131 & 1.131 & 1.131 & 1.131 & 1.131 \\
\hline Dig. threonine (\%) & 0.735 & 0.735 & 0.735 & 0.735 & 0.735 \\
\hline Calcium (\%) & 0.758 & 0.758 & 0.758 & 0.758 & 0.758 \\
\hline Avail. phosphorus (\%) & 0.354 & 0.354 & 0.354 & 0.354 & 0.354 \\
\hline Sodium (\%) & 0.200 & 0.200 & 0.200 & 0.200 & 0.200 \\
\hline Chlorine (\%) & 0.324 & 0.328 & 0.332 & 0.337 & 0.341 \\
\hline $\begin{array}{l}\text { Potassium }(\%) \\
\text { Number of Mongin }(\mathrm{mEg} / \mathrm{kg})\end{array}$ & $\begin{array}{c}0.810 \\
202.68\end{array}$ & $\begin{array}{c}0.810 \\
201.60\end{array}$ & $\begin{array}{c}0.810 \\
200.52\end{array}$ & $\begin{array}{c}0.811 \\
199.43\end{array}$ & $\begin{array}{c}0.811 \\
198.35\end{array}$ \\
\hline
\end{tabular}

$0.65 \mathrm{mM}$ blood glycerol, whereas this level increased for $4.36 \mathrm{mM}$ in birds fed $5 \%$ dietary glycerol and ranged between 11.24 and $54.17 \mathrm{mM}$ when the diet was supplemented with up to $20 \%$ glycerol. The blood glycerol levels obtained in the present bioassay, ranging between $15 \mathrm{mg} / 100 \mathrm{~g}(1.80 \mathrm{mM})$ and $85 \mathrm{mg} / 100 \mathrm{~g}(9.00$ $\mathrm{mM}$ ) in broilers fed up to $10 \%$ glycerine, are lower than those observed by those authors.

According to Robinson \& Newsholme (1969), the enzymatic capacity of glycerol transformation in the body is limited, and when its consumption exceeds this capacity, it may not be completely metabolized, thereby increasing its blood levels. Lammers et al. (2008) observed that finishing pigs can metabolize up to $10 \%$ glycerol in the diet, and Ponciano Neto (2011) reported that dogs present greater glycerol metabolization capacity than other non-ruminant animals. However, in broilers, the inclusion of $10 \%$ glycerol in the diet exceeds broilers' capacity to metabolize glycerol, thereby increasing blood glycerol levels (Gianfelici, 2009).

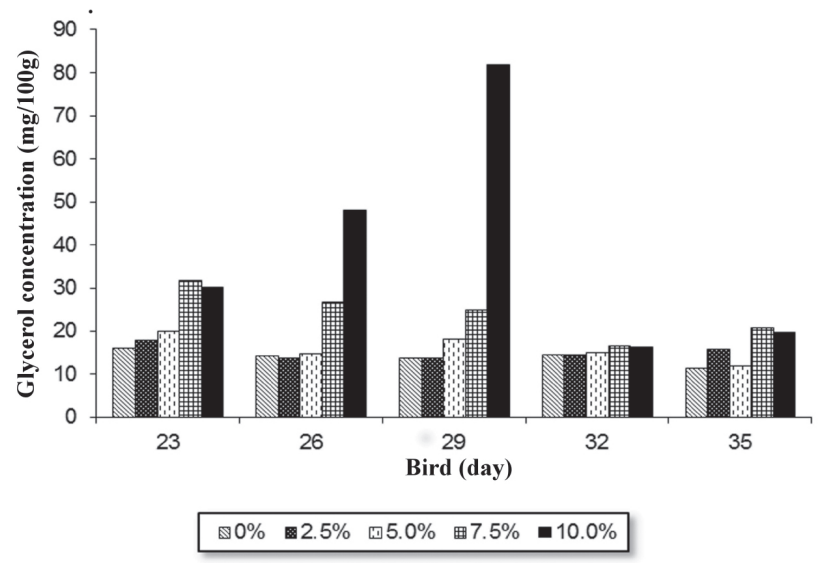

Figure 1- Blood glycerol concentration of 23- to 35-d-old broilers fed increasing dietary crude glycerin levels. 
Table $\mathbf{5}$ - Ingredients and calculated nutritional composition of the finisher diets.

\begin{tabular}{|c|c|c|c|c|c|}
\hline \multirow[b]{2}{*}{ Ingredients } & \multicolumn{5}{|c|}{ Glycerine inclusion (\%) } \\
\hline & 0 & 2.5 & 5.0 & 7.5 & 10.0 \\
\hline Ground corn & 60.461 & 57.495 & 54.525 & 51.560 & 48.568 \\
\hline Soybean meal & 31.854 & 32.350 & 32.846 & 33.343 & 33.845 \\
\hline Soybean oil & 4.768 & 4.858 & 4.948 & 5.037 & 5.135 \\
\hline Glycerine & 0.000 & 2.500 & 5.000 & 7.500 & 10.000 \\
\hline Dicalcium phosphate & 1.095 & 1.099 & 1.103 & 1.106 & 1.110 \\
\hline Calcitic limestone & 0.796 & 0.792 & 0.790 & 0.786 & 0.783 \\
\hline Salt & 0.444 & 0.330 & 0.216 & 0.103 & 0.000 \\
\hline DL-methionine & 0.243 & 0.246 & 0.250 & 0.252 & 0.256 \\
\hline L-lysine $\mathrm{HCl}$ & 0.163 & 0.154 & 0.145 & 0.136 & 0.126 \\
\hline L-threonine & 0.026 & 0.026 & 0.027 & 0.027 & 0.027 \\
\hline Vitamin supplement $^{1}$ & 0.060 & 0.060 & 0.060 & 0.060 & 0.060 \\
\hline Choline chloride $60 \%$ & 0.040 & 0.040 & 0.040 & 0.040 & 0.040 \\
\hline Mineral supplement ${ }^{2}$ & 0.050 & 0.050 & 0.050 & 0.050 & 0.050 \\
\hline \multicolumn{6}{|l|}{ Calculated values } \\
\hline ME (kcal/kg) & 3.200 & 3.200 & 3.200 & 3.200 & 3.200 \\
\hline $\mathrm{CP}(\%)$ & 19.48 & 19.47 & 19.45 & 19.44 & 19.42 \\
\hline Dig. met+cys (\%) & 0.774 & 0.774 & 0.774 & 0.774 & 0.774 \\
\hline Dig. methionine (\%) & 0.504 & 0.505 & 0.507 & 0.508 & 0.509 \\
\hline Dig. lysine (\%) & 1.060 & 1.060 & 1.060 & 1.060 & 1.060 \\
\hline Dig. threonine (\%) & 0.689 & 0.689 & 0.689 & 0.689 & 0.689 \\
\hline Calcium (\%) & 0.663 & 0.663 & 0.663 & 0.663 & 0.663 \\
\hline Avail. phosphorus (\%) & 0.309 & 0.309 & 0.309 & 0.309 & 0.309 \\
\hline Sodium (\%) & 0.195 & 0.195 & 0.195 & 0.195 & 0.199 \\
\hline Chlorine (\%) & 0.317 & 0.321 & 0.325 & 0.330 & 0.341 \\
\hline $\begin{array}{l}\text { Potassium (\%) } \\
\text { Number of Mongin }(\mathrm{mEq} / \mathrm{kg})\end{array}$ & $\begin{array}{c}0.758 \\
189.25\end{array}$ & $\begin{array}{c}0.758 \\
188.17\end{array}$ & $\begin{array}{c}0.759 \\
187.09\end{array}$ & $\begin{array}{c}0.759 \\
186.01\end{array}$ & $\begin{array}{r}0.760 \\
184.98 \\
\end{array}$ \\
\hline
\end{tabular}

'Supplied per kg diet: Vitamin A, 5,400 IU; Vitamin D3, 1,500 IU; Vitamin E, 12 IU; Vitamin K3, 1.5 mg; Vitamin B1 (thiamin), 0.9 mg; Vitamin B2 (riboflavin), 3.6 mg; Vitamin B6 (pyridoxine), $1.8 \mathrm{mg}$; Vitamin B12 (cyanocobalamin), $7.2 \mu$; Pantothenic acid, $7.2 \mathrm{mg}$; Niacin, $15 \mathrm{mg}$; Folic acid, 0.48 mg; biotin, $0.036 \mathrm{mg}$; selenium, $0.15 \mathrm{mg}$. ${ }^{2}$ Supplied per kg diet: $\mathrm{Cu}, 10 \mathrm{mg} ; \mathrm{Fe}, 50 \mathrm{mg} ; \mathrm{Mn}, 75 \mathrm{mg} ; \mathrm{Co}, 1 \mathrm{mg} ; \mathrm{l}, 1 \mathrm{mg} ; \mathrm{Zn}, 50 \mathrm{mg}$.

Glycerol is metabolized mainly in the liver and kidneys, but other tissues, such as the brain, lungs, intestinal mucosa, adipose tissue, skeletal and heart muscles, leukocytes, fibroblasts, and sperm also use glycerol, but in small amounts (Stryer et al., 2008). Vernon \& Walker (1970) showed that the enzyme glycerol kinase is the limiting factor of glycerol metabolism. Lin et al. (1976) reported that the use of glycerol depends on the enzymes glycerol kinase and dehydroxyacetone phosphate dehydrogenase. When their capacity is exceeded, glycerol can no longer be metabolized, and consequently, excreted by the body. It is assumed that excessive glycerol is excreted in the urine, particularly at high dietary inclusion levels (Bartelt \& Schneider, 2002; Dasari, 2007; Gianfelici, 2009).

Excessive dietary glycerol may induce anatomical, physiological, and biochemical adaptation, especially of the liver and also of the kidneys (Cryer \& Hartley,
1973). Lin et al. (1976) studied the effect of glycerine on the lipogenic activity of rats and broilers and showed that the $20 \%$ addition in the diet of rats for three weeks increased liver weight and promoted a marked increase in the activity of liver lipogenic enzymes. However, in broilers, no changes in liver weight and a decrease in the activity of lipogenic enzymes were observed.

In the present study, however, no color changes or lesions were observed during the gross examination of the livers of broilers at sacrifice, which is consistent with Kijora et al. (1995), who did not find any liver or kidney changes in pigs fed diets with up to $10 \%$ glycerine inclusion.

Also, liver glycerol concentrations were not significantly different ( $p>0.05)$ among treatments, whereas Simon et al. (1997) found that glycerol concentration increased from $18 \mu \mathrm{mol} / \mathrm{g}$ to $40 \mu \mathrm{mol} / \mathrm{g}$ in the liver of broilers fed 0 to $25 \%$ glycerol. 
There was no significant difference $(p>0.05)$ in total cholesterol and triacylglycerol blood levels between the control group and those fed diets with different glycerine inclusion levels.

Figure 2 shows the water consumption results of the broilers fed increasing glycerine levels. There was an interaction $(p<0.05)$ between glycerine levels and bird age. At 4 days of age, the broilers fed diets with 2.5, 7.5 , and $10 \%$ crude glycerine presented significantly higher $(p<0.05)$ water consumption. Also, at 8 days of age, water consumption was significantly higher in the treatments fed 5.0. 7.5, and $10 \%$ glycerine, but there were no statistical differences ( $p>0.05$ ) in water intake at the other evaluated ages. The increase in water consumption observed on days 4 and 8 may be related to an adaptation period of the birds fed glycerine. It must be noted that sodium levels were corrected when formulating the diets.

Gianfelici (2009) evaluated daily water consumption of broilers fed $0,2.5,5.0,7.5$, and $10 \%$ glycerine between 21 and 38 days of age and observed an increase in water consumption and excretion at glycerine levels of $7.5 \%$ and higher. The results of the present study do not agree with the findings of Gianfelici (2009) possibly because that author, when formulating the experimental diets, did not take into account glycerine sodium levels, which may have exceeded broilers' sodium nutritional recommendations. According to Simon et al. (1997), the increase in water consumption and excretion may be influenced by glycerine sodium or potassium levels, which may vary as a function of the processing method used to obtain this product.

There was an effect of the interaction $(p<0.05)$ between glycerine levels and bird age on feed intake. At 8 and 12 days of age, the broilers fed 2.5 and $7.5 \%$ crude glycerine presented higher feed intake than those fed $10.0 \%$ glycerine (Figure 3 ). At the other evaluated ages, there were no differences in feed intake. Simon et al. (1997), Cerrate et al. (2006), and Silva (2012) evaluated glycerine inclusion in broiler diets and concluded that high dietary levels of glycerine increased feed intake on the first days of rearing. However, in the present study, feed intake increased only at the level of $2.5 \%$ dietary glycerine, disagreeing with aforementioned studies that showed that feed intake increased as a function of increasing dietary inclusion of glycerine. Also, our results are different from the findings of Fernandes et al. (2012), who did not observe any effect on feed intake when including $0,2.5,5.0,7.5,10.0$, or $12.5 \%$ distilled glycerine in the diet of 1-to 8-d-old broilers. On the other hand, Silva et al. (2012) reported that feed intake increased as glycerine inclusion levels increased in the diets of 22- to 34-d-old broilers.

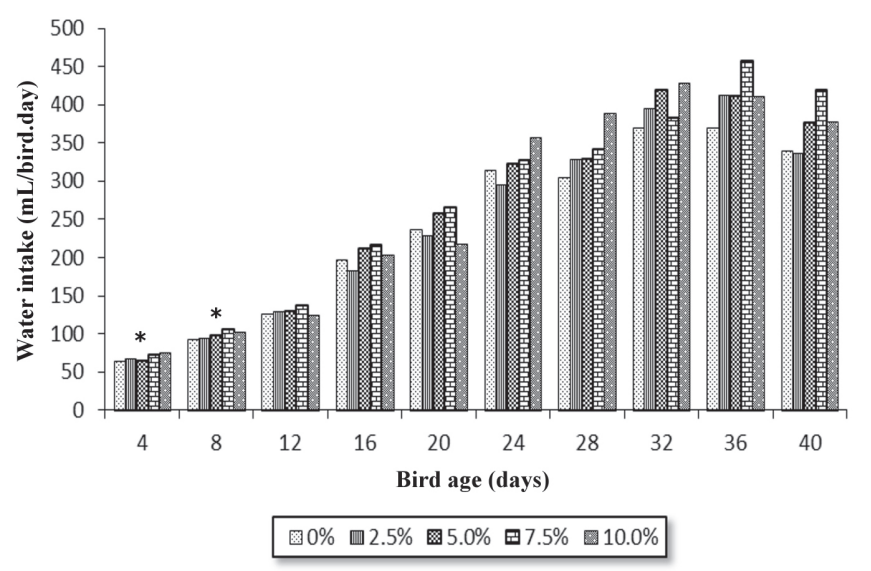

*Significant effect by the $\mathrm{F}$ test at $5 \%$ probability level

Figure 2 - Water consumption of 1 - to 40 -d-old broilers fed increasing dietary crude glycerin levels.

The results obtained from 16 to 40 days of age (Figure 4) show that the birds fed 5.0, 7.5, and 10.0\% crude glycerine presented significantly higher $(p<0.05)$ fecal moisture at 16 and 20 days of age, but not at the other evaluated ages. This is consistent with the findings of Gianfelici (2009), who observed significant increase in fecal moisture in broilers fed high glycerine levels. Boso (2011) evaluated the inclusion of crude and semi-purified glycerine in layer diets, and reported that excreta moisture increased as dietary glycerine level increased, attributing this result to the glycerine sodium levels (1.990 and $1.040 \%$ for crude glycerine and semi-purified glycerine, respectively). Cerrate et al. (2006) also found increased litter moisture when $10 \%$ glycerine in broiler feeds, and argued that this was possibly due to the $0.15 \%$ excess in potassium derived from the residue of the catalyzer used in the transesterification reaction. Silva et al. (2012) evaluated the inclusion of increasing glycerine levels in broiler diets and detected increased litter moisture in the birds fed $10 \%$ glycerine after the third week of rearing. Therefore, in the present study, no association between water consumption and excreta moisture, as influenced by dietary glycerine levels, was detected. It must be noted that, after 32 days of age, the excreta of broilers fed diets with 7.5 and $10 \%$ glycerine had an appearance of diarrhea, possibly due to excessive glycerol that was excreted in the urine.

There were no differences ( $p>0.05)$ among treatments as to ileal digesta moisture (data not presented). These results are consistent with those of Gianfelici (2009), who did not find any effect of dietary glycerine on ileal content moisture. 


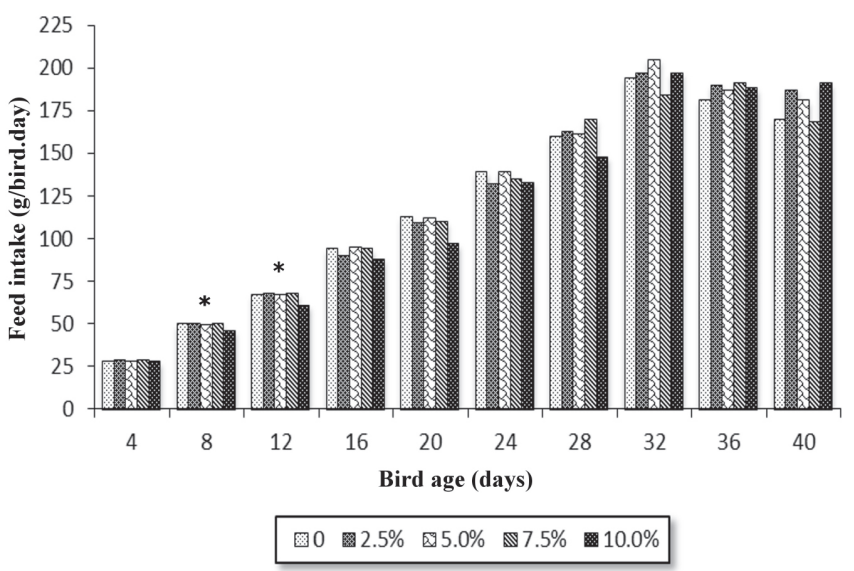

* Significant effect by the $\mathrm{F}$ test at $5 \%$ probability level

Figure 3 - Feed intake of 1- to 40-d-old broilers fed increasing dietary crude glycerin levels.

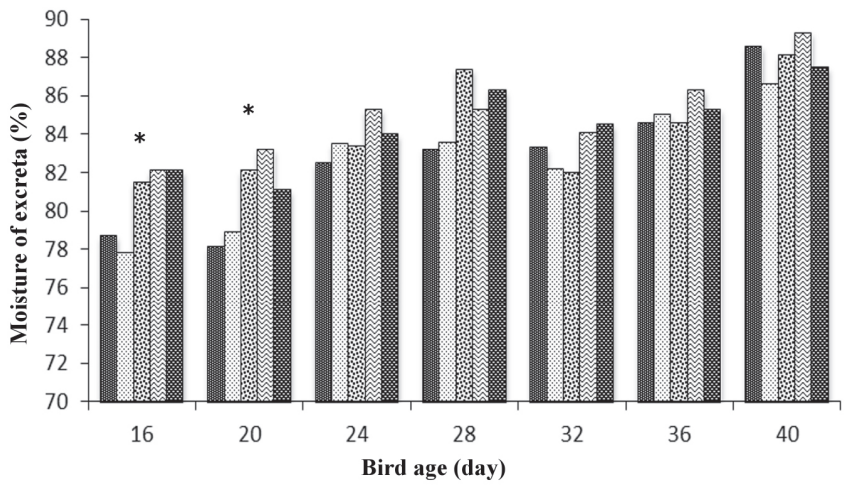

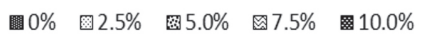

${ }^{*}$ Significant effect by the $\mathrm{F}$ test at $5 \%$ probability level

Figure 4 - Excreta moisture of 1- to 40-d-old broilers fed increasing dietary crude glycerin levels.

\section{CONCLUSIONS}

Broilers are capable of adequately metabolizing glycerol when the diet contains up to $7.5 \%$ crude glycerine, but unfavorable metabolic changes may be present when higher levels are fed.

\section{REFERENCES}

Bartlet J, Schneider D. Investigation on the energy value of glycerol in the feeding of poultry and pig. Union for the Promotion of OilseedsSchriften Heft 2002;17(1):15-36.

Belusso D, Hespanhol AN. evolução da avicultura industrial brasileira e seus efeitos territoriais. Revista Percurso 2010;2(1):25-51.

Boso KMO. Utilização de diferentes tipos de glicerina na alimentação de poedeiras comerciais [dissertation]. Maringá (PR): Universidade Estadual de Maringá; 2011.

Cerrate SE, Yan F, Wang Z, Coto C, Sacakli P, Waldroup PW. Evaluation of glycerine from biodiesel production as a feed ingredient for broilers. International Journal of Poultry Science 2006; 5(11):1001-1007.
Cryer A, Hartley W. Studies on the adaptation of rats to a diet high in glycerol. International Journal of Biochemestry 1973;4(21):293308,1973 .

Dasari MA. Crude glycerol potential described. Feedstuffs 2007; 79(1):16-19

Emmanuel B, Berzins R, Robblee AR. Rates of entry of alanine and glycerol and their contribution to glucose synthesis in fasted chickens. British Poultry Science 1983;24(4):565-571.

Fernandes ML, Barbosa FC, Santos ET, Silva FF, Dourado RLB, Farias LA. Glicerina na alimentação de frangos de corte de 1 a 8 dias de idade criadas em baterias metálicas. Anais da $49^{\circ}$ Reunião Anual da Sociedade Brasileira de Zootecnia; 2012; Brasília, DF. Brasil. p.1-3.

Gianfelici M.F. Uso de glicerol como fonte de energia para frangos de corte [dissertation]. Porto Alegre (RS): Universidade Federal do Rio Grande do Sul; 2009.

Hansen CF, Hernandez A, Mullan BP, Moore K, Trezona-Murray M, King $\mathrm{RH}$, Pluske JR. A chemical analysis of samples of crude glycerol from the production of biodiesel in Australia, and the effects of feeding crude glycerol to growing-finishing pigs on performance, plasma metabolites and meat quality at slaughter. Animal Production Science 2009;49(1):154-161.

Kijora C, Bergner H, Kupsch RD, Hageman L. Glycerol as a feed component in fattening pigs. Archives of Animal Nutrition 1995;47(4):345-360.

Lammers PJ, Kerr BJ, Weber TE, Dozier WA, Kidd MT, Bregendahl K, Honeyman MS. Digestible and metabolizable energy of crude glycerol for growing pigs. Journal of Animal Science 2008; 86(1):602-608.

Lin $\mathrm{MH}$, Romsos DR, Leveille GA. Effect of glycerol on lipogenic enzyme activities and on fatty acids synthesis in the rat and chicken. Journal of Nutrition 1976;106(1):1668-167

Lin ECC. Glycerol utilization and its regulation in mammals. Annual Review of Biochemistry 1977; 46(1):765-795.

Lumeij JT. Avian clinical biochemistry. $5^{\text {th }}$ ed. San Diego: Academic; 1997

Ponciano Neto B. Uso de glicerina na alimentação de cães adultos [dissertação]. Maringá (PR): Universidade Estadual de Maringá; 2011.

Peres JRR, Freitas Jr E, Gazzoni DL. Biocombustiveis. Uma oportunidade para o agronegócio brasileiro. Revista de Política Agrícola 2005;1(1):31-41.

Pond WG, Church DC, Pond KR, Schoknecht A. Basic animal nutrition and feeding. $5^{\text {th }}$ ed. Hoboken: John Wiley \& Sons; 2005.

Robergs RA, Griffin SE. Glycerol: biochemistry, pharmacokinetics and clinical and practical applications. Sports Medicine 1998;26(3):145-167.

Robinson J, Newsholme A. The effects of dietary conditions and glycerol concentration on glycerol uptake by rat liver and kidney-cortex slices. Journal of Biochemistry 1969;112(4):449-453.

Rosebrough RW, Geis E, James P, Ota H, Whitehead J. Effects of dietary energy substitutions on reproductive performance, feed efficiency and lipogenic enzyme activity on large white turkey hens. Poultry Science 1980;59(7):1485-1492.

Rostagno HS, Albino LFT, Donzele JL, Gomes PC, Oliveira RF, Lopes DC, Ferreira AS, Barreto SLT. Tabelas brasileiras para aves e suínos composição de alimentos e exigências nutricionais. $3^{a}$ ed. Viçosa: UFV; 2011.

SAS Institute. SAS user's guide. 9.2 ed. Cary; 2010

Silva CLS, Menten JFM, Traldi AB, Pereira R, Zavarize KC, Santarosa J. Glycerine derived from biodiesel production as a feedstuff for broiler diets. Brazilian Journal of Poultry Science 2012; 14(3):159-232. 
Silva JV, Santos NC, Ribeiro DF, Barbosa EC, Silva PP, Dourado RLB. Glicerina na alimentação de frangos de corte no período de 22 a 34 dias de idade. Anais da $49^{a}$ Reunião Anual da Sociedade Brasileira de Zootecnia; 2012; Brasília, DF. Brasil. p. 45-48.

Simon A, Bergner H, Schwabe M. Glycerol as a feed ingredient for broiler chickens. Archives of Animal Nutrition 1996; 49(2):103-112.

Simon A, Schwabe M, Bergner H. Glycerol supplementation in broiler rations with low crude protein content. Archives of Animal Nutrition 1997;50(3):271-282.

Stryer L, Tymoczko JL, Berg JM. Bioquímica. $6^{a}$ ed. Rio de Janeiro: Guanabara Koogan; 2008.

Swartz ME. Ultra performance liquid chromatography (UPLCTM). LCGC North America 2005; 8(1):8-14.

Vernon RG, Walker DG. Glycerol metabolism in the neonatal rat. Biochemical Journal 1970; 118(3):531-536. 